\title{
Self-efficacy analysis of EFL student with digital game experiences
}

\author{
M. N. Diya Alhaq1, Nur Arifah Drajati², M. Sri Samiati Tarjana3 \\ Universitas Sebelas Maret ${ }^{1,2,3}$ \\ ${ }^{1}$ Correspondence: artazgang@student.uns.ac.id
}

\begin{abstract}
The English lessons in the school curricula are designed to be a benchmark of student foreign language competency measurement. To succeed in every single aspect of the lesson, students need to enhance their will and motivation so they can fulfil all the needs and complete it. Self-efficacy is one of the most critical factors which can sustain student academic intention amongst all. Thus, the role of experience is one of the factors which can keep a prominent way of developing functional self-efficacy. As a form of experience, playing a video game (also known as gaming behaviour) is the one who considered valuable in hoisting the effectiveness of student's English learning, especially in developing the existence of student's self-efficacy. Some students in different stages of formal education schools like elementary, and senior high scholars with different specifications toward the experience and the characteristics of self-efficacy will be the object of this research. Using a descriptive qualitative approach, six students from a different grade and school are analysed and proved in having self-efficacy toward English lesson. This thing implies that students that have some experiences in playing digital games are provided with selfefficacy and appears more dominant than the students without such experiences.
\end{abstract}

Keywords: analysis, digital game, English as a foreign language, experiences, self-efficacy

\section{Introduction}

English as the most common universal language settles into a form which measured as the proper language and communication standard in the various modern field and aspects like in business, professional services, and occupation, cultural, and also the scientific activity. As a result, English tends to be an absolute subject within every formal education and solid higher education requirement, thus, all students in the school learn it (Drubin and Kellogg, 2012). The English lessons in the school curricula are designed to be a benchmark of student foreign language competency measurement. To succeed in every single 
aspect of the lesson, students need to enhance their will and motivation so they can fulfil all the needs and complete it. Self-efficacy is one of the most critical factors which can sustain student academic intention amongst all (Bandura, 1997). The existence of self-efficacy within the student academic life, which is close to the characteristic of purposefulness, is essentials since it can boost the performance of the student in the lessons. This thing can drive the students in making a particular goal, planning the future strategies, and keeping them high spirited also sturdy - especially when encountering the difficulties of the foreign language learning process, in this case, the English (Bandura, 2006).

More importantly, one of the most basic factors of human life, i.e. the experience can significantly develop self-efficacy (Bandura, 1997). The specific individual experiences keep a significant role in maintaining self-efficacy: the positive one will increase it, while the negative one will decrease it (Martinez, et al., 2017). In the matter of education, the experience is fundamental since it leans and correlates to the human interaction with the environment amongst them. Experience grasps primary role within it - encompass some phenomenon like communicative, and cultural (Hohr, 2013). As a form of experience, playing a video game (also known as gaming behaviour) is the one who considered valuable according to the latest research. Video game, or within the same term as 'computer' or 'digital' game, is believed by some experts can improve the effectiveness of learning activity and process (Hung et. al., 2018; Chee, 2016; Peterson, 2012; Prensky, 2001; Reinders, 2012; Reinhardt, \& Sykes, 2014). The environments within the games give learners such a save learning environments which can provide an unlimited chance to grind their knowledge, ability, and skills without having any anxiety in the process (Prensky, 2005). Since the purpose of formal education is to gain knowledge, learning and its process, appears as a quantitative process in which the result can be measured and countable. From that perspective, playing a game can be considered as meaningful as learning (Chee, 2016). In the matter of language learning, the implementation of digital games within it mainly leaned to the idea that a good language learning process always corresponds with the learner social life factors and enhances the participation of lifetime learning experience. Therefore many experts believe that nowadays, technology, which also includes digital games, can support both the learning process, either within or outside the classroom walls (Reinders, 2012).

Some research has already discussed the role of technology toward selfefficacy (Chen, 2014; Henderson et al., 2009; Nelson, \& Ketelhut, 2008; Shank, \& Cotten; 2014). Especially in some research, technology focused on the role of the digital game (Yang, 2015; Davis, \& Lang, 2012; Meluso et al., 2012). Hence, those studies did not further discuss the gameplay experiences of the students with self-efficacy - the main factor for describing the student characteristics. Since digital games can increase the effectiveness of the language learning 
process, students who have gaming experiences are expected to have a functional self-efficacy within the English subject. However, to specify the student with the characteristic, people need to know what kind of gaming experiences that need to be possessed. It is essential since there is no specific limitation for the gaming experience, and most of them mend for amusement. The objects of the research are students in various stages of formal education school i.e. elementary, and senior high scholars, with different specification toward the experience and the characteristics of self-efficacy. Researcher will choose some students from each grade with no strict standard or criterion for their school, environment, and background, since gaming experience as the only indicator which needs to be possessed by them. Thus, this research is expected to analyse whether students who possessed the digital game experience have enough self-efficacy in English lesson within the scope of formal education and to describe whether the degree of the behaviour determines the existence of self-efficacy within their self.

\section{Literature review}

\section{The digital game experience}

The renaissance of Digital Game era as a new option in language teaching and learning process, especially within the scope of English, began to start after a contemporary concept in exploiting the latest technology is discovered. The concept, which later will be known as Computer-Assisted Language Learning or CALL, emerged back in 1982 after that term is firstly proposed by Davies and Steel (1981) within their research paper (Thomas, et. al.. 2013). Considering its innovative and non-conservative characteristics, the practices and studies regarding CALL embrace to unlock the full potential of computer (digital) technology for the enhancement of teaching and learning activities. Thus, the development of CALL technologies grows significantly - evolving from just a simple form of gap-filling exercises into an interactive multimedia-based technology (Beatty, 2010). This progress has happened coincidentally with the emergence of digital game technology. Its unique characteristic then intrigued many experts and researchers to observe more about it (Dalgarno, \& Lee, 2010; Cerezo, et al., 2019; Eklund, 2015; Hung, et al., 2018; Yang, 2015). Most of them are talking about the capabilities of digital/video game elements for supporting language learning if arranged significantly. Thus, those researches confirmed the connectedness of CALL approach with digital games (Peterson, 2012).

As part of the CALL, the study of the inclined language learning process toward the basis of the digital game is discussed within the scope of Digital GameBased Language Learning or DGBLL (Hung et al., 2018). Not only digital game as a learning method and media, but DGBLL also covered digital gaming 
behaviour, especially the degree of gaming experiences. Since the role of experience within the human is not meant to drive men away from (their) nature, instead to makes them more aware about the essence of it (Dewey, 1925), the transformation of the experiences into knowledge can ignite the occurrence of the learning process (Kolb, 1984). In the matter of digital gaming experiences, Kallio, Mäyra, and Kaipainen (2011) introduce the model of gaming mentalities: Intensity, Sociability, and Games (InSoGa) to render the classifications of gamer, the gaming behaviours, and custom, also defining some essential component of every aspect correlated with gaming. This thing is significant since the gaming activities is currently evolving into a dynamic millennial culture which embracing a massive human diversity across the globe (Kallio, Mäyra \& Kaipainen, 2011). Thus, by promoting lucid ways in differentiating them, many concepts for future studies regarding this concern can be arranged.

Therefore, the digital gaming behaviour and experiences are also considered important toward the development of self-efficacy within the gamer self (Yang, 2015). Since the gaming experiences include the immersion of the gamers, it is clear that gaming experience is influencing both of the cognitive condition and social relation (Cairns, et al., 2000). It is suited with what Alexiou and Schippers (2018) have said that gaming technology has offered a new option for a contemporary learning design which can be developed and applied into a formal educational environment. Then, along with it, the classification of the gaming experiences will be primary (Kallio, Mäyra \& Kaipainen, 2011) since it can help to determine the existence of self-efficacy within the self of EFL student with gaming experiences.

In that case, this study is implementing the InSoGa model of gaming mentalities to measure the degree of gaming experiences of EFL students, along with some characteristics of self-efficacy, in order to analyse self-efficacy of the EFL student with gaming experience.

\section{The digital game experience upon self-efficacy}

As Bandura (1997) said, self-efficacy is someone's faith or believe toward the abilities to control and perform the way of activities in achieving things. Especially in the matter of the learning, Joët et al. (2011) described it as the students or learners assurance toward their competencies and abilities to finish the assignment and another requirement within the teaching and learning activities. Moreover, self-efficacy can also help the student in arranging purposes, predicting the suitable future strategies, and planning some learning structures (Bandura, 2006; Shank \& Cotton, 2014; Henderson et. al., 2009). In that case, the existence of self-efficacy is one of the primary aspects that student needed, especially in the EFL subject (Bandura, 1997). 
In developing the existence of self-efficacy, the experience is regarded as one of the crucial elements (Bandura, 1997; Chen, 2014; Davis, \& Lang, 2012; Henderson et al., 2009; Joët et. al., 2011). In the first place, people are born as infants without any awareness of personality and ego to comprehend the selfagency. The mind and personal characteristics need to be developed utilizing experience from the interaction with the surrounding. The advancements rises along with some steps: capturing factitive correlation on the events which happening amongst them, realizing the consequences of their actions whether it is proactive or contradictive, and recognizing self as the actions-motor (Bandura, 2006). As the result, people with more experience will face benefits like they tend to be more aware toward their behaviour and attitude (Petty, et al., 2007), also have a specific characteristic which differs them with another person (Bandura, 2006). Since many experts believed that the use of digital gaming activities has a significant impact toward the development of self-efficacy (Bawa et al., 2018; Hopp, et al., 2015; Klimmt \& Hartmann, 2008), the students with specific gaming experiences might also carry out the characteristics too.

Then, the gaming experiences need to be appropriately classified in order to find the level of sociocultural diversity between the gamers itself (Kallio, Mäyra \& Kaipainen, 2011). According to this model, there are three components which will be used in classifying the gaming mentalities: the intensity of the gameplay, the sociability of the gamers, and the game diversities. Moreover, all of them will be divided again into three separate dimensions. The intensity consists of three viewpoints: length of gaming sessions, the regularity of gaming, and the level of concentration; the sociability includes three spaces i.e., physical, virtual, and outside game; and for the game, it covers three components viz. individual games and devices, game genres, and accessibility. It is essential to define the degree of gaming experiences since the in-game immersion is different between one gamer to the others (Cairns, et al., 2000; Bawa, et al., 2018).

There are many studies which already talks about digital game and selfefficacy. As an instance, Davis and Lang (2012) questioning 493 consumers to find out whether there is any relationship between self-efficacy, game purchase, and usage. They concluded that there are significant aspects of the relationship between all those three. In other studies about virtual world, language, and selfefficacy, Henderson, et. al., (2009) examined 100 students enrolled in Chinese language and culture studies at Monash University to find out whether collaborative language activities within a designated immersive virtual world, in this case, they are using Second Life, could improve students' self-efficacy beliefs about their capacity to use Chinese language in a variety of real-life contexts. The result shows that there are significant improvements between pre- and post-test. Also, Zheng, et. al., (2009) conducted a study about self-efficacy, English, and digital game. They involved 61 seventh grade students in finding out whether the 
use of a virtual world game can offer a suitable environment for improving efficacy in English. It was figured out that the virtual world may offer suitable space for English learner to improve confidence and comfort while eliminating the cultural barrier.

From these studies, it can be concluded that through the exposure of digital gaming, self-efficacy can be developed. Furthermore, from some intense gaming behaviours and experiences, it is believed that self-efficacy does exist within the self of the student. In that case, this study will focus on analysing the self-efficacy within the EFL student with gaming experiences which correspond with the degree of their gaming experience based on InSoGa model of gaming mentalities.

\section{The research framework}

This study was constructing a research framework which was shown in Figure 1, in order to describe the analysis of EFL student self-efficacy with digital game experiences briefly.

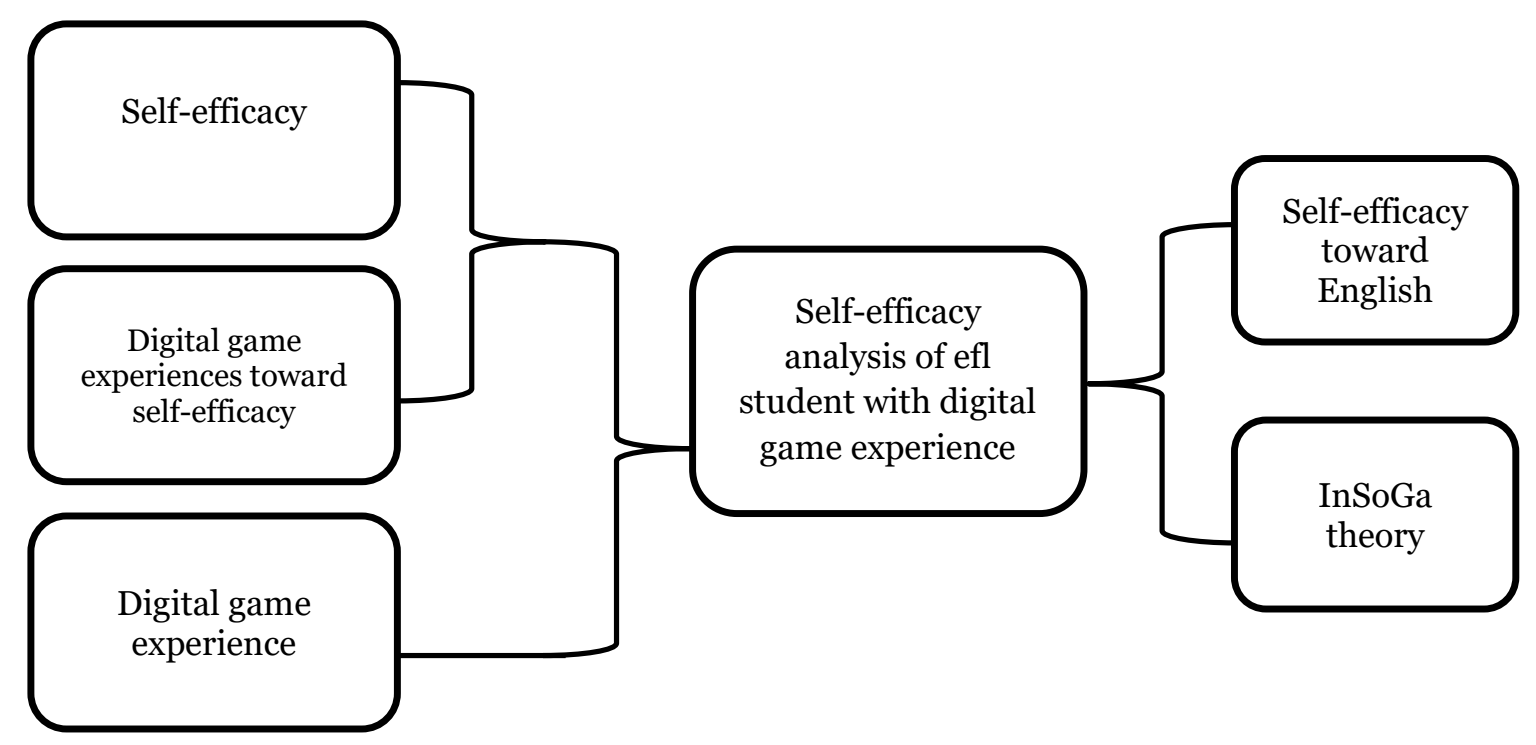

Figure 1. Research framework

Based on the figure, it can be seen that self-efficacy is related to the person's conscious feeling or sense regarding their own abilities and capacity which can let the person maintain good mental condition in various circumstances. Thus, there are some specific characteristics which can be seen from students with and without self-efficacy (Sedikides \& Gregg, 2007; Kristjánsson, 2010; Maclellan, 2007; Goel \& Anggarwal, 2012; Tuncel, 2015; Atherton, 2015). Then, a digital game can also increase students' English self- 
efficacy. Furthermore, it improves students' learning motivation, selfidentification, and bonding; has empathy with others, widens the gaze and interest, expand the sense of ownership and responsibility (Chiang, et. al., 2011; Lu, et. al., 2011).

Moreover, Digital game experience can be described as a kind of particular experience which sustained by the player/gamer (person who plays the game) from the anticipation before acquiring the game to the urge of playing the game again and again after it. The measurements consist of the intensity of playing, players' sociability, and numbers of the games. During that moment, the player/gamer will counter some psychological condition like forceful emotions, increased control awareness, concentration, and cognitive rush (Cairns, et. al., 2012; Alexiou \& Schippers, 2018; Kallio, Mäyrä \& Kaipainen, 2007). From those points, then this study is regulated as an awareness which relied on people's competence and worthiness, cognition and affection. Also, stability and openness noted within specific characteristic and supports the learner within the lesson. This awareness comes from the digital gameplay experiences that can be seen from their intensity of playing, players' sociability, also the numbers of the games, since the digital games are proved to be able in maintaining some benefits regarding student self. Thus, to find out the middle way between them, this study would encounter the self-efficacy toward English by using the InSoga theory.

\section{Method}

This study discovers the self-efficacy of EFL students with digital gaming experiences which are believed to have significant learning performances (Yang, 2015). To collect the data, the interview sessions were suggested by Yang as an appropriate method for studying the self-efficacy (Yang, 2015). The descriptive (or also known as survey research) qualitative research was chosen as a suitable methodology when studying digital gaming (see Alhaq, 2018; Ary, et. al., 2006). Then, the data analysed by using the Interactive Model, which Miles and Huberman proposed, consisting of several steps like data collection, reduction, display, and drawing conclusion/verification (Miles \& Huberman, 1994). The data collected from the interviews were reduced then displayed in order to be displayed and verified through literature reviews also expert theories/opinions.

\section{Participants}

The data comprise of individual interviews conceded in Lampung, Indonesia, in 2019. A purposed snowball sampling was used, as the researcher tends to dive into the natural environment where the instances occurred. In line with this purpose, the sampling technique could embrace the respondent participation in 
pointing another respondent which ensemble with the object of study criteria (Johnson \& Christensen, 2014). Some EFL students from a different grade and school were chosen, five of them were senior High School (HS) students (tenth grader), and one of them was an Islamic elementary school (ES) student within Metro area (fourth grader). The study criteria, which is informed to the respondent, were "EFL students who often played digital games". Once the study facts were informed, the researcher selected a respondent who was believed to have the capacity as a respondent. Then, that "first" respondent was asked to find/point other relatives for being the next respondents. In case for the technical feature of this method and sampling, see Ary, et. al., (2006).

\section{Procedure}

The descriptive approach is the one which applied to this research. It is chosen because of its appropriateness with the purpose of this research in analysing the digital gaming experiences on students' self-efficacy on English subject. Procedures with some steps are used for a descriptive approach, some of them are: (1) Determining research focus and research questions formulation. This research will concentrate on the data which are taken from the observation; (2) Determining data collection and description. The data descriptions will be attached directly after the data which are needed is completely collected; (3) Analysing the data. From the description, the data will be analysed by using several instruments; (4) Drawing conclusion and evaluating. Some evaluation and data conclusion will be drawn regarding its reliability and authenticity; (5) Writing some report. The writer will make a report to simplify the data, consists of data summary and its formality (Miles \& Huberman, 1994).

\section{Data collection}

This research comprises some data collecting instruments i.e. observation and interview session. Observation is one of the research instruments by which the researcher does some intense social interactions with the object in its latest environment and time-period which are low-profiled and systematically collected in the form of field notes (Wilkinson \& Birmingham, 2003). Some field notes which are taken will help the researcher in drawing some patterns and characteristic that happened in the natural settings. Since the data will be gathered inside its platform to meet the natural settings, the researcher directly dive in into the game and become the player. Then the researcher will observe all the parts in the game which maybe suit with as the language learning elements.

The interviews were held within the same signatures and questions format. Open questions were asked within the in-depth interviewing style (Creswell, 2007). The data collected would be examined as the physical evidence 
for determining the degree of digital gaming experiences and their impact toward self-efficacy of English subject. All of the interviews were documented in the form of video, and the dialogs were translated also transcribed.

\section{Data analysis}

The data analysis techniques which are used in this research is the Interactive Model which proposed by Miles and Huberman (1994). The researcher systematically carryout the steps during the data analysis process, which they are: data collection, reduction, display and drawing conclusion/verification. The data which already been collected will be analysed by using this cycle:

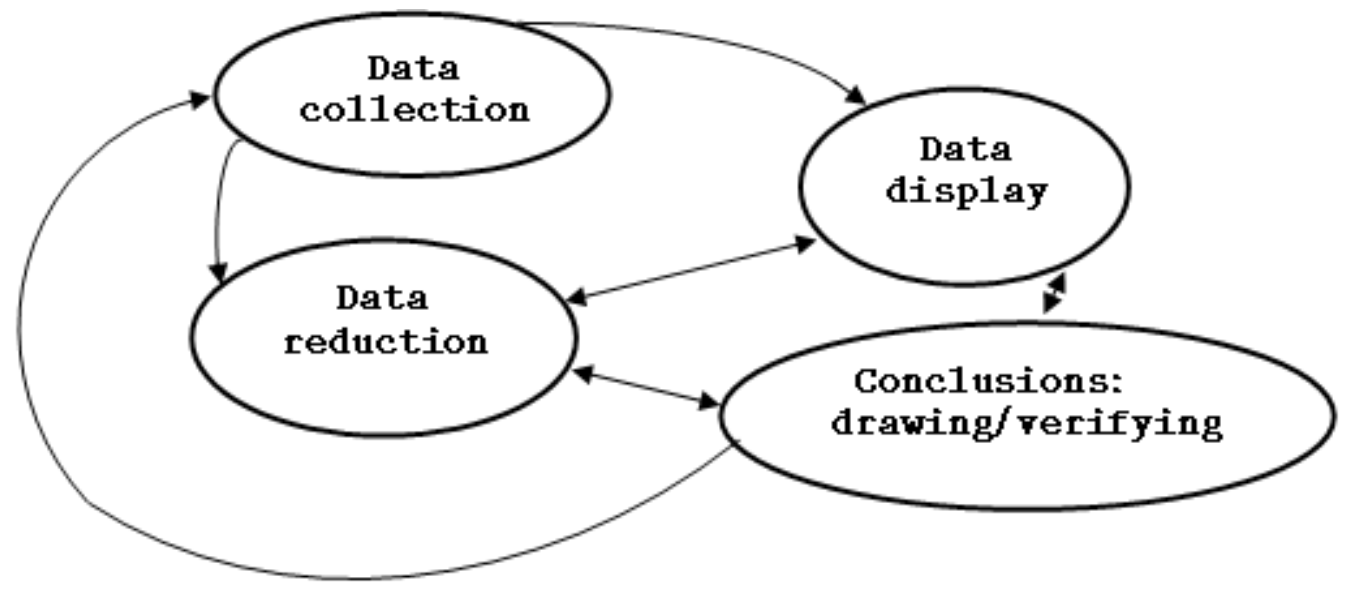

Figure 2. Components of Data Analysis: Interactive Model

This model consists of four steps which are described with the following: (1) Data collection. The first steps include the data collection as the primary moves before analysing the data; (2) Data reduction. During the process, some data will be choose comply with the specific needs and summarized; (3) Data display. The data then will be displayed in the form of graphics, figures or charts so can be seen and describe the entire process; (4) Data conclusion or verification. As the result, some conclusion and verifications will be drawn regarding the data reliability and authenticity.

\section{Findings and discussion}

The respondents of the study consist of all male EFL students who have a span of age between 11 to years 17 old. All the respondents played the digital game 
regularly, and most of them recently played the latest online mobile digital game like Player Unknown Battleground (Tencent Game, 2018), Free Fire (Garena, 2017), Mobile Legend Bang Bang (Moonton, 2016), and Clash of Clans (Supercell, 2012). All the respondents have ever played more than five digital games titles with various genres and platform. Since the online mobile digital game was the most affordable online gaming platform, all the respondents were often playing together, whether in online or offline gathering activity. The high school respondents also establish a gaming team or also called as 'squad'.

The advance breakthrough of Internet technology let nowadays digital game mostly played online. Those supportive characteristics let all the respondents played interactively with other gamer and seldom only gamed alone. Thus, Table 1 and Table 2 shows the data extracted from the questions of the interview session.

Table 1. The research's data description and respondents' data summary of gaming experiences

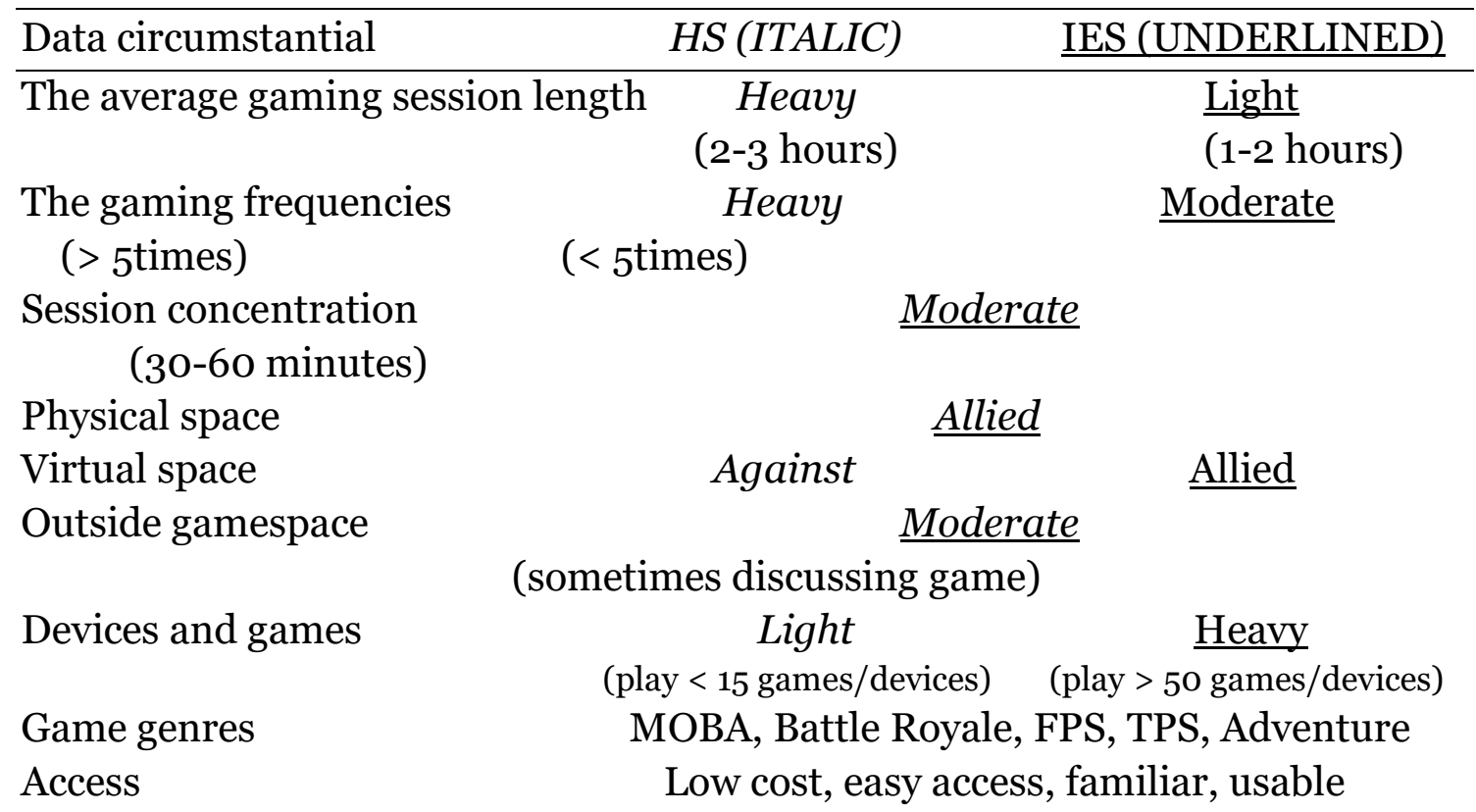

The subsequent sections discover the essence of digital gaming toward self-efficacy and English subject. There are four different themes which are simultaneously connected and summarized within the paragraphs below.

\section{The digital game experience toward self-efficacy}

Researcher : With the intake you received from playing games, do you have any confidence in learning English?

Respondent (1) : : "Yes, I feel more confident. Especially since many English vocabularies can be taken from English-registered game." 
The digital game nowadays commonly made by using English as its main language. Moreover, many digital games, especially online, which equipped with many language options. This language-option feature is believed as a sign language learning element which can boost the effectiveness of English learning (Alhaq, 2018). The digital games are also believed which can enhance their player's vocabulary (Zheng, et., al., 2009). Moreover, the digital gameplay also can increase the students' motivation in learning English especially vocabulary. The utilization of digital games is better proved to be an excellent strategy for the teacher in teaching vocabulary (Shahriarpour \& Kafi, 2014).

The Respondent 1 also joined the English Club extracurricular activity in his school. He said that he chose to join the English Club since he liked the English subject and wanted to learn more about it.

\section{The self-efficacy toward English competitive awareness}

Researcher : Do you feel superior in English subjects compared to your classmates who are not gamers?

Respondent (6) : : "Yes, most of my friends are not gamers. I feel like no one in my class has a better grade than me for the English subject."

Many experts have already proved within some various studies that digital game-based language learning has an excellent outcome toward the EFL students' self-efficacy and confidence. Moreover, the intimate digital gaming experiences also can ignite the willingness to communicate within the target language. (Hung, et al., 2018).

Respondent 6 also showed some language skills which tend so stood out compared with other students on that age. It was so sure since during the interview session Respondent 6 showed champion certificate, for the winning in English Speech Competition, competing with all representative of all Islamic Elementary School in Lampung Province.

\section{The digital game experiences on English difficulties}

Researcher : : Do you feel that your experience in playing games contributes significantly to the process of learning English in the classroom?

Respondent (2) : : "It helped me to get some things within the English subject, but it wasn't too significant."

Respondent (3) : :Yeah, it helped me a lil' bit, not so much. Despite that, game makes me curious about the subject and wants to learn 


\section{English more."}

There are many studies which already proved the Digital Game-Based Language Learning as a useful way to gain much insight in the case of language learning. The most common English competencies are DGBLL for improving vocabulary (Hwang \& Wang, 2016). Furthermore, the DGBLL also give a significant impact for the autonomous learning process (Hung et al., 2018).

Even though the Respondent 2 and Respondent 3 believed that digital game were not too helpful for them in learning English, but they prefer to be exposed with the English through the digital game, even though the in-game option allowed them to change the language-register into their mother tongue.

\section{The digital game experiences toward English competencies}

Researcher : Can you mention an English sentence that you might hear from a game?

Respondent (5) : :Yes, I've ever heard a sentence like "I get supply."

Respondent (6) : I know some sentences, but the one that really came from the game was "Evil and demon are weak!"

Not only vocabulary, English learning through the digital game also hoists the effectiveness of writing skill. Suh et., al., (2010) found that the EFL students who exposed with the MMORPG game experiences had outperformed the test score of the students that not engaging in digital gaming activities. The gaming activities also proved that they could increase listening and reading learning effectiveness.

Respondent 5 and Respondent 6 admitted that the sentences which they heard from the game were so attached within their head since they played the game a lot. It helped them in recognizing the English sentence structure and memorizing the vocabularies with ease.

\section{Conclusion}

This study discovered the existence of self-efficacy within EFL students with digital gaming experiences. The results of this study obviously have a 'notuniversal-characteristic' since the data reflection showed a not exact outcome. Thus, this study summarizes that the digital game situated people in developing self-efficacy within English learning and provides them with academic awareness contributes to some language competencies, yet motivates facing some learning difficulties even not too significant. When this latest entertainment technology encouragement on behalf of EFL student perceptual progression, the advance language learning media in the digitalized form sustenance autonomous learning 
which boost the effectiveness of language learning and teaching activities. Moreover, that phenomenon clarifies the significance of digital media implementation for language learning, especially English. The digitalized learning media, in this case, digital game, shows great potential in overcoming the nowadays challenges and contemporary academic needs. The computerized one will minimize the student's learning effort, thus maximize the success rate of English learning and teaching activities.

Another point of this study confirms that in case one wants to stimulate operative language learning activities, regarding the mental state of students is a significant component. The experience in playing the digital game increases selfefficacy and academic awareness. Not only stop in that point, but the online feature of latest internet improvement which applied in the most recent digital games also destroys the conventional thought about a game that says "digital/video game makes it is player solitary." Games are able, through their schemes, to upkeep the social interactions both in the real and cyber world.

The final things which we can see as this study's conclusion are that the digital game tends to form language competencies. Most of the player will be exposed with a large extent of language elements. In that case, second language acquisition process has occurred. The digital gaming experience also embraces the latest phenomenon of informal digital learning of English or commonly known as IDLE. This latest venture of language learning with advanced technology enhancement is proved to be able to maintain an active learning process.

Along with those conclusions, the digital game, thus, is evolving. Not only the digital game is becoming a useful language learning media, but also The EFL students with the digital game experience need to be considered as an effective learner which employing prompt autonomous learning. Further research about this study, consequently, must be deepened so that people will considerate more about this topic. As the present findings are restricted for the specific sample group, more elaborative studies are needed.

\section{References}

Alexiou, A., \& Schippers, M. (2017). Digital game elements, user experience and learning: A conceptual framework.

Ary, D., Jacobs, L. C., \& Sorensen, C. K. (2010). Introduction to research in education. Canada: Wadsworth Cengage Learning.

Atherton, M. (2015). Measuring confidence levels of male and female students in open access enabling courses. Issues in Educational Research, 25(2), 81.

Bandura, A. (1997). Self-efficacy: The exercise of control. Macmillan.

Bandura, A. (2006). Guide for constructing self-efficacy scales. Self-efficacy beliefs of adolescents, 5(1), 307-337. 
Bawa, P., Walson, S. L., \& Watson, W. (2018). Motivation is a game: Massively multiplayer online games as agents of motivation in higher education. Computers \& Education 123, 174-194.

Beatty, Ken. (2010). Teaching and Researching; Computer-Assisted Language Learning. London: Pearson Education Limited. Educ. Inf. Technol. doi.org/10.1007/s10639-018-9730-6.

Cerezzo, R., Calderon, V., \& Romero, C. (2019). A holographic mobile-based application for practicing pronunciation of basic English vocabulary for Spanish speaking children. International Journal of Human-Computer Studies 124,13-25.

Cairns, P., Cox, A., \& Nordin, A. I. (2014). Immersion in digital games: Review of gaming experience research. Handbook of Digital Games, 1, 767.

Chen, Y-L. (2014). A Study on student self-efficacy and technology acceptance model within an online task-based learning environment. Journal of Computers, Vol. 9, No. 1.

Chiang, I. T., Shih, R. C., Liu, E. Z. F., \& Lee, A. J. Y. (2011, September). Using game-based learning and interactive peer assessment to improve career goals and objectives for college students. In International Conference on Technologies for E-Learning and Digital Entertainment (pp. 507-511). Springer, Berlin, Heidelberg.

Creswell, J. W. (2017). Qualitative inquiry and research design: Choosing among five approaches. SAGE publications.

Davis, R., \& Lang. B. (2012). Bridging the online/offline divide: The example of digital gaming. Journal of Retailing and Consumer Services 19, 67-77.

Davis, R., \& Lang, B. (2012). Modeling the effect of self-efficacy on game usage and purchase behavior. Journal of Retailing and Consumer Services, 19(1), 67-77.

Dalgarno, B., \& Lee, M. J. W. (2010). What are the learning affordances of 3-D virtual environments? British Journal of Educational Technology, Vol. 41 No. $1,10-32$.

Dewey, J. (1929). Experience and nature. London: George Allen \& Unwin, LTD.

Drubin, D. G., \& Kellogg, D. R. (2012). English as the universal language of science: opportunities and challenges. Molecular biology of the cell, 23(8), 1399. doi:10.1091/mbc.E12-02-0108

Eklund, L. (2015). Bridging the online/offline divide: The example of digital gaming Computers in Human Behavior 53, 527-535.

Goel, Manisha, and Preeti Aggarwal. A comparative study of self-confidence of single child and child with sibling. International journal of research in social sciences 2.3 (2012): 89.

Henderson, M., Huang, H., Grant, S., \& Henderson, L. (2009). Language acquisition in second life: Improving self-efficacy beliefs. Proceedings Ascilite Auckland.

Hohr, H. (2013). The concept of experience by John Dewey revisited: Conceiving, feeling and enliving. Studies in Philosophy and Education, 32(1), 25-38.

Hopp, T., Barker, V., \& Schmitz Weiss, A. (2015). Interdependent self-construal, self-efficacy, and community involvement as predictors of perceived knowledge gain among MMORPG players. Cyberpsychology, Behavior, and Social Networking, 18(8), 468-473. 
Hung, H-T., Yang J. C., Hwang, G-J., Chu, H-C., \& Wang, C-C. (2018). A scoping review of research on digital game-based language learning. Computers \& Education 126, 89-104.

Hwang, G. J., \& Wang, S. Y. (2016). Single loop or double loop learning: English vocabulary learning performance and behavior of students in situated computer games with different guiding strategies. Computers \& Education, 102, 188-201.

Joët, G., Usher, E. L., \& Bressoux, P. (2011). Sources of self-efficacy: An investigation of elementary school students in France. Journal of educational psychology, 103(3), 649.

Johnson, B., \& Christensen, L. (2008). Educational research: Quantitative, qualitative, and mixed approaches. SAGE.

Kallio, K. P, Mayra, F., \& Kaipainen, K. (2011). At Least Nine Ways to Play: Approaching Gamer Mentalities. Games and Culture 6(4) 327-353.

Klimmt, C., \& Hartmann, T. (2008). Mediated interpersonal communication in multiplayer video games. Mediated interpersonal communication, 309.

Kolb, D. A. (2014). Experiential learning: Experience as the source of learning and development. FT press.

Kristjánsson, K. (2010). The self and its emotions. Cambridge University Press.

Lu, H. M., Lou, S. J., Papa, C., \& Chung, C. C. (2011, September). Study on influence of adventure game on English reading confidence, motive and self-efficacy. In International Conference on Technologies for E-Learning and Digital Entertainment (pp. 430-434). Springer, Berlin, Heidelberg.

M. N. D. Alhaq. (2018). An analysis of language learning elements in Clash of Clans Game, Undergraduate Thesis (pp. 47.)

Maclellan, E. (2014). How might teachers enable learner self-confidence? A review study. Educational Review, 66(1), 59-74.

Martínez EA, Villa OES. (2017). A quantitative study of self confidence in learning English as a foreign language. Acad. J. Educ. Res. 5(2): 024-028.

Meluso, A., Zheng, M., Spires, H. A., \& Lester, J. (2012). Enhancing 5th graders' science content knowledge and self-efficacy through game-based learning. Computers \& Education, 59(2), 497-504.

Miles, M. B., Huberman, A. M., Huberman, M. A., \& Huberman, M. (1994). Qualitative data analysis: An expanded sourcebook. SAGE.

Nelson, B. C., \& Ketelhut, D. J. (2008). Exploring embedded guidance and selfefficacy in educational multi-user virtual environments. International Journal of Computer-Supported Collaborative Learning, 3(4), 413-427.

Peterson, M. (2012). EFL learner collaborative interaction in second life. ReCALL, 24(1), 20-39.

Petty, R. E., Briñol, P., Tormala, Z. L., \& Wegener, D. T. (2007). The role of metacognition in social judgment. Social Psychology: Handbook of basic principles, 2, 254-284.

Prensky, M. (2005). Computer games and learning: Digital game-based learning.

Prensky, M. (2001). Digital natives, digital immigrants part 1. On the horizon, 9(5), 1-6.

Reinders, H. (Ed.). (2012). Digital games in language learning and teaching. Basingstoke, England: Palgrave Macmillan. 
Reinhardt, J., \& Sykes, J. (2014). Special issue commentary: Digital game and play activity in L2 teaching and learning. Language Learning \& Technology, 18(2), 2-8.

San Chee, Y. (2015). Games-to-teach or games-to-learn: Unlocking the power of digital game-based learning through performance. Springer.

Shahriarpour, Nahid \& Zahra Kafi. (2014). Procedia - Social and Behavioral Sciences, 98. p. $1738-1743$.

Sedikides, C., \& Gregg, A. P. (2007). Portraits of the self. SAGE Handbook of Social Psychology, 93-122.

Shank, D. B., \& Cotten, S. R. (2014). Does technology empower urban youth? The relationship of technology use to self-efficacy. Computers \& Education, 70, 184-193.

Suh, S., Kim, S. W., \& Kim, N. J. (2010). Effectiveness of MMORPG-based instruction in elementary English education in Korea. Journal of Computer Assisted Learning, 26(5), 370-378.

Thomas, M., Reinders, H,. \& Warschauer, M. (2013). Contemporary computerassisted language learning. London: Bloomsbury Publishing Plc.

Tunçel, H. (2015). The relationship between self-confidence and learning Turkish as a foreign language. Educational Research and Reviews, 10(18), 25752589.

Wilkinson, David, \& Birmingham, Peter. (2003). Using research instruments: A guide for researchers. Routledge-Falmer. p. 116.

Yang, J. C., Quadir, B., \& Chen, N-S. (2015). Effects of the badge mechanism on self-efficacy and learning performance in a game-based English Learning Environment. Journal of Educational Computing Research, o(o) 1-24.

Zheng, D., Young, M. F., Brewer, R. A., \& Wagner, M. (2009). Attitude and selfefficacy change: English language learning in virtual worlds. CALICO Journal, 27(1), p-p 205-231. 